\title{
Developing Students' Writing Skill By Using Picture Media
}

\author{
Winda Widyaningrum \\ Rr.Astri Indriana Octavita
}

\author{
English Language Education Department \\ Universitas Indraprasta PGRI Jakarta \\ widyaningrumwinda@yahoo.com
}

\begin{abstract}
Writing is one of the basic skills in learning English. For some students learning writing is still difficult, especially how to develop ideas into interesting writing. A teacher must be able to apply learning methods that are fun and actively involve students in the learning process, also use appropriate learning media that it can attract students' interest to make learning writing easier. This research is aimed to understand how to develop students' writing skill by using picture as an alternative media. The method of the research is a classroom action research. It used three cycles and each cycle consisted of four steps; planning, acting, observation and reflecting. It was conducted at the Teacher College with the total population 50 students. Data needed was obtained from observation, interview and test. The result of the test has shown that there is positive feedback given from students through the use of picture media in writing teaching. It can be proven by the result of the test in each cycle which shown. The first cycle, the students got the average score 71,3 (43\%). In the second cycle, they got the average score 74,6 (71,4\%). While in the third cycle, they got 76,8 (90,5\%). Base on the fact above the researcher concluded that picture media is effective to develop students' writing skill.
\end{abstract}

Key words: language learning, writing skill, picture media

\section{Introduction}

All around the world, students of all ages learning to speak English, but their reasons for wanting to study English can differ greatly. Some students, of course, only learn English because it is on the curriculum at primary or secondary level, but for others, studying the language reflects some kind of a choice. Many people learn English because they have moved into a target language community and they need to be able to operate successfully within that community. A target language community is a place where English is the national language. Many people learn English because they think it will be usefull in some way for International communication. Such students of general English often do not have a particular reason for going to English classes, but simply wish to learn to speak, read and write the language effectively for whenever this might be usefull for them. There are many reasons for getting students to write, both in and outside class. Firstly, writing gives them more thinking time than they get when they attempt spontaneous conversation. This allow them more opportunity for language processing whether they are involved in study or activation. The kind of writing we ask students to do (and the way we ask them to do it) will 
depend, as most other things do, on their age, level, learning styles and interests. One of our decisions about what to get students to write will depend on what genres we think they need to write in or which will be useful to them. When thingking about writing, it is helpful to make distinction between writing-for-learning and writing-and-writing. In the case of the former, writing is used as an aide-memoire or practice tool to help students practice and work with language they have been studying. Writing-for writing is directed at developing the students' skills as writers. In other words, the main purpose of this activity is that students should become better at writing, whatever kind of writing that might be.

Based on the observation, most of students are still difficult to achieve those targets because their knowledge of English is still low primarily in writing. Based on the interview result with the teacher concerning students' writing test, there are some difficulties faced by students in writing activities such as: difficulty in gaining idea, lack of vocabulary, low grammar mastery, and low student motivation in learning writing. After knowing the cause of the problem, need an interesting way for a student in learning English to solve their problems. One of the alternative media that can be used is picture media. It can be used as one effort to deal with the students' difficulties in the teaching and learning process of writing.

The picture media is effective in giving lessons to the students because this media is interesting and simple to apply. The use of picture media is proper in teaching writing, because the media is easy to get. This learning model can generate original ideas and trigger creativity in thinking. It also helps students express ideas in their initial form, development, including the characters and setting a story should have.

\section{Theoretical Review}

Writing is a process, not a product. This means that a piece of writing, whether it is composition for your English class is never complete, that is, it is always possible to review and revise. There are four main stages in the writing process: prewriting, planning, writing and revising drafts, and writing the final copy to hand in. It provides a leaner with physical evidence of his achievements and they can measure their improvement. Sentence is the base of an article. So they should begin their writing with sentences. For example, translation, sentence pattern exchanging, and text shortening and rewriting. It helps to understand the text and write compositions. It can foster the leaner's ability to summarize and to use the language freely.

Description of performance Intermediate levels; writing (adapted by Paltridge from the IELTS test, 1992):

Ideas and argument: Limited range of ideas expressed. Development may be restricted and often incomplete or unclear. Information is not arranged coherently.

Accuracy: $\quad$ Limited grasp of lexical, grammatical, and relational patterns and use of cohesives devices. Weaknesses in punctuation and/or spelling.

Fluency: $\quad$ Texts may be simple, showing little development. Limited structures and vocabulary. Little subtiety and flexibility.

Appropriateness: Use of language generally appropriate to function, text type, and communicative goal within a limited range of text types. Layout generally appropriate to text type.

Intelligibility: $\quad$ Can convey basic meanings, although with some difficulty.

Picture is a sketch of objects visualized in a surface of paper, board, wall, etc. In teaching media, it belongs to visual aid. Picture as media is able to motivate students, to make the 
subject they are dealing with clearer, and to illustrate the general idea and forms of an object or action which are particular to a culture. Picture is excellent stimuli for both writing and speaking. For example, we can play a film and the students have to imagine and then write out the film scene they think it could accompany (this can be done after they have looked at a film script model). We can dictate the first sentence of a story and then have the students complete the story, based on the film we play them. We can dictate the first sentence again and have them write a different story (because the film they hear is very different). They can then read out one of their stories and the class has to guess which film excerpt inspired it.

According to Harmer $(2007: 118)$ that picture offer a wealth of possibilities. We can ask students to write descriptions of one of a group of pictures; their classmate then have to guess which one it is. They can write postcards based on pictures we give them. We can get them to look at potraits and write the inner thoughts of the characters or their diaries, or an article about them. All of these activities are designed to get students writing freely, in an engaging way.

Wright (1989) adds that pictures give contribution to students' interest and motivation, sense of language in context, and stimulate students' ideas. The roles of pictures in productive skills (speaking and writing) are:

1. Picture can draw students' motivation and attention and make them participate in learning.

2. Pictures can create contextualized language learning activity.

3. Pictures may raise interpretation objectively and subjectively.

4. Pictures may refer to response of questions, or as controlled practices.

5. Pictures can stimulate and give information in dealing with conversation, story telling and discussion.

$\mathrm{He}$, furthermore, mentions that there are five practical criteria of pictures to be applied in the classroom, (1) easy to prepare, (2) easy to organize, (3) interesting, (4) meaningful and authentic, and (5) sufficient amount of the language in order to justify its conclusion in the language lesson.

Heaton (1990:107) stated that, in everyday life, students may sometimes be required to describe people, objects, places, and even processes. There will also be times when they will have to write about sequences of events, incidents, etc. and give directions. Pictures provide students with ideas for such tasks, enabling them to give their full attention to using written language.

Based on the some theories above, the researcher can write a synthesis that picture media is an image associated with the subject matter that serves to convey a message from the teacher to the student. Picture are good used in learning language because they can help the students to visualize language from abstract to concrete one easily.

\section{Research Methodology}

This research is Classroom Action Research. As for design classroom action research which is used in this study is to use a model of Kemmis and McTaggart. The model composing four steps: planning, acting, observing and reflecting. Theoretically an action research should be undertaken in the class, together with the process of teaching and learning. This research was conducted in three cycles applying the model proposed by implementing actions using picture media in teaching and learning process. 
Data description provide by qualitative analysis, it explains about the result of writing score in every cycle by comparing score result of writing test that attained in every cycle.

The Average Score of Passing Grade Score Each Cycle

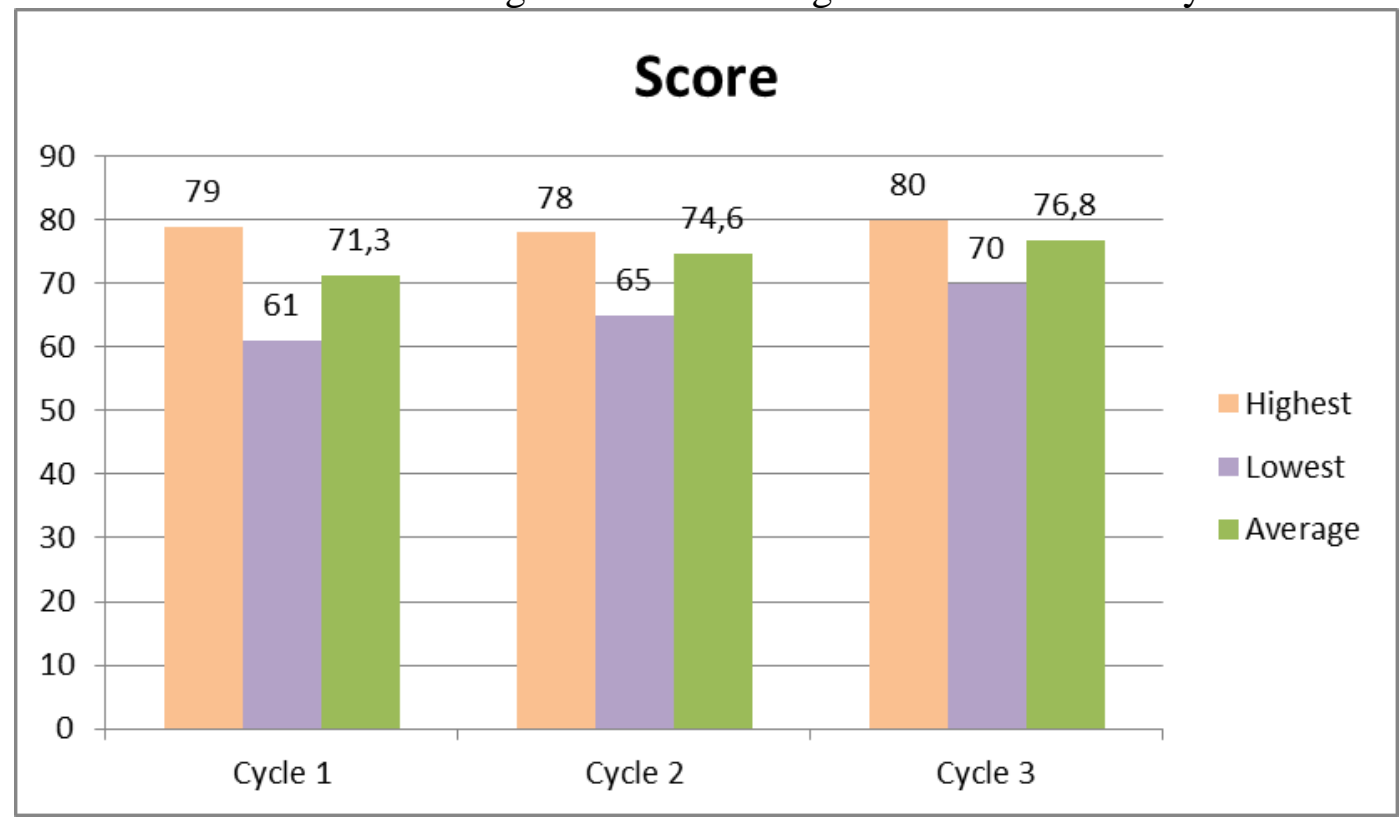

In the above diagram shows that the average score in cycle 1 is 71,3 , the cycle 2 is 74,6 , the cycle 3 is 76,8, represent the students' score average is more increased and it was the students improvement on the students achievement.

Then, the researcher would like also to show the diagram of passing students in each of the cycles.

This is needed to do as it is easier to show the data in the graphic. It can be seen as follows:

Graphic student's cycle presentage in Cycle 1, Cycle 2 and Cycle 3

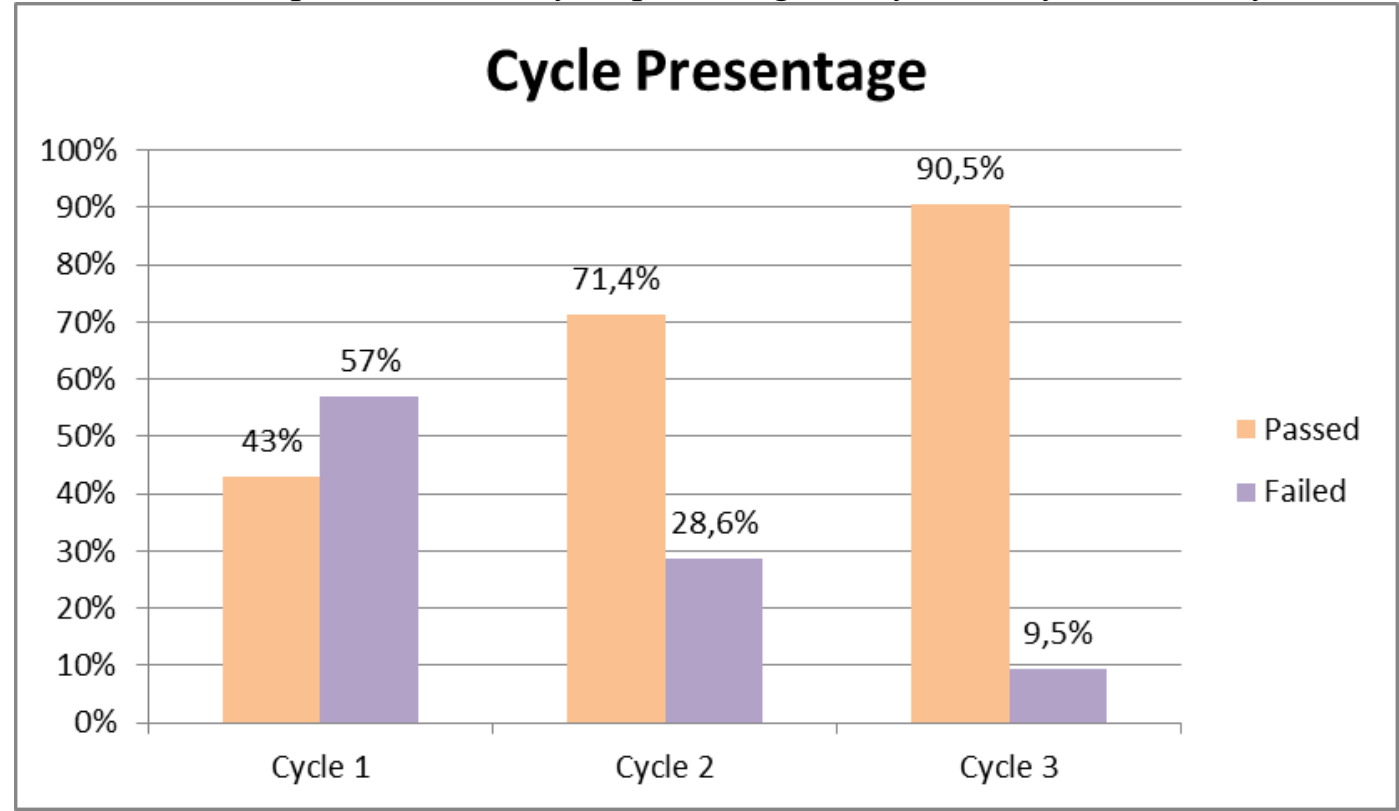


Based on the graphic above it can be seen that the average of passing students are also improved in each of the cycle 1 there are 43\%, In Cycle 2 there are 71,4\% and in cycle 3 $90,5 \%$ students are passed.

Based on the result above, it can be seen the hypothesis of this research was accepted. Teaching learning by using picture media can develop students' writing skill.

\section{Findings and Discussion}

According to findings in the cycle 1, cycle 2, and cycle 3 that this research is focusing on the implementation of using picture media can develop writing skill. Based on interviewed with students and Collaborator, Collaborator said that many students can writing descriptive text and the students get high score when writing, especially writing a descriptive text. And also it based on the students' score the result of their score can be explained as follows:

In cycle 1 , the average score posttest 1 obtained by the students' scores is 71,3 . The researcher analyze it is mean only 9 students (43\%) students success passing the grade score and the students interest joining the processing of learning that the students have difficulties in learning writing because they were lack of grammar, vocabulary and also they still confused to start writing and difficult to construct the idea. Besides, the students felt bored in teaching learning process. This mean figure show that the students' writing skill was low and need to be improve. This problem absolutely needed a solution. And picture media as the solution related to this problem.

In cycle 2, the researcher has knowing the problem of the students in learning writing, so the researcher improved the lesson plan based on the characteristics of the students of seventh grade in the class and also the researcher gave motivation to them in learning writing. The result of the posttest 2 showed the increasing average score was 74,6. Beside, 15 students $(71,42 \%)$ sucessfull could pass the grade score. This improvement was a good signal that convinced the researcher to do the research. The students were excited an pay attention with the picture media. However the students still lack to express the ideas well. Therefore the cycle continued to cycle 3 .

In cycle 3 , the result of the posttest 3 showed the increasing average score of 76,8. But the study has not got the target in which $100 \%$ the students get passing grade score. Only $90,5 \%$ student passed in this cycle. The researcher is observe, so many factors why they can't reach the target. There are, they lack in vocabulary and grammar, they can't get the idea when they write descriptive text, they still confuse to make a descriptive text even the researcher explained the lesson.

Based from cycle 1, cycle 2, and cycle 3 that the process of study of writing skill on descriptive text through picture media, the students has an improvement with their writing skill with getting the target score 76,8. Even though there were 2 students are failed in the last cycle and so many problems in the classroom but the researcher could solve them. The researcher assumed the result of the writing test conducted after cycle procedures while showing the list of the result students' test and the process of study gets the achievement. 


\section{CONCLUSION}

To conclude the research, the researcher would like to state the following conclusions. There are some conclusions as follows:

In teaching learning process by using picture media can improve students' writing skill. The effect of this research is teaching learning process by using picture media can develop students' writing skill. There are developments in the students' vocabulary, grammar mastery, their self-confidence, and their motivation in learning English. It can be seen in the post.

Besides that, by using picture media can gain understanding on the process of teaching writing. It can be shown from observation. Observations sheet including the class situation, student's motivation, interactive students and student's ability in doing post test.

\section{References}

Brown, J. W. Lewis, R. B. And Harcleroad, F.F. 1983. Audio Visual Instruction.

New York: McGraw Hill, Inc.

Chan, Michelle. 1989. Process and Product. New York: Coller-Macmillan.

Graddol, D. 2006. EFL,ESL,ESOL,etc:on the changing face of English and English Teaching. The British Council.

Harmer. 2007. Theory and Practice of Writing. Oxford: Oxford University Press.

Heaton, J. B. 1990. Classroom Testing. New York: Longman

Madsen, Harold S. 1983. Techniques in Testing. Oxford: Oxford University Press

McMahan, Elizabeth. 1996. Literature and Writing Process. New Jersey: Prentice-Hall.

Oshima, Alice. 1991. Writing Academic English. Longman.

Richards, Jack C. 2001. Curriculum Development in Language Teaching. Cambridge: Cambridge University Press.

Wishon, George E. and Burks, Julia M.. 1980. Let's Write English. New York: Litton Educational Publishing.

Wright, A. 1989. Pictures for Language Learning. Cambridge: Cambridge University Press. 